\title{
Nord Stream, the Environment and the Law: Disentangling a Multijurisdictional Energy Project
}

\author{
David Langlet
}

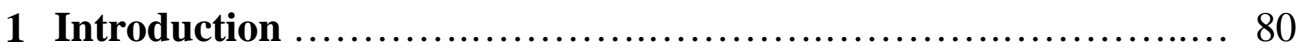

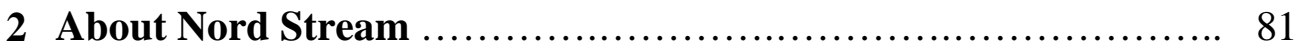

3 International and EU Law Premises $\ldots \ldots \ldots \ldots \ldots \ldots \ldots \ldots \ldots \ldots, 83$

3.1 Issues of Jurisdiction ...................................... 84

3.2 The Legal Status of Nord Stream and its Implications ............ 88

3.3 Environmental Protection .................................... 90

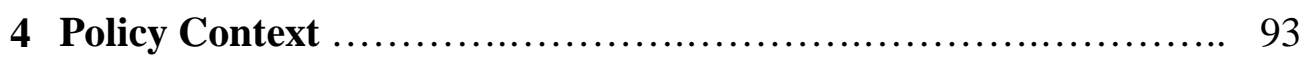

5 The Permit Procedures ......................................... 98

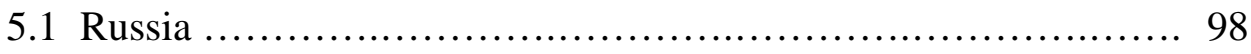

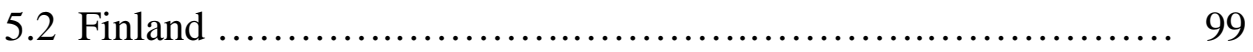

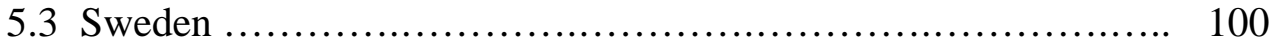

5.4 Denmark .................................................... 102

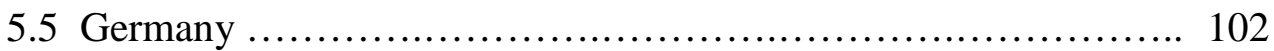

5.6 Comparison and Conclusions .............................. 104

6 General Conclusions ........................................ 107 
Introduction

The Nord Stream gas pipeline is one of the largest and doubtless most controversial energy infrastructure projects in Europe. In addition to technical and political challenges the project has navigated a web of substantive and procedural legal issues spanning five national jurisdictions in addition to EUand international law.

The present article takes a closer look at the legal and policy context in which the idea of a submarine gas pipeline from Russia to Germany materialized and the national permit processes preceding its construction. The project's transboundary nature, and the fact that it engages various areas of law, makes it an attractive case for analysing the consistency and dynamics between these areas, or spheres, of law. While the primary concern here is the construction and application of rules pertaining to the protection of the environment these are also inextricably linked to rules defining the competences of different actors, and thus their ability to exercise jurisdiction over, and be held responsible for, the effects of the pipeline.

When analysing decisions on submarine transit pipelines regard must be had to the fact that international law, in the form of the United Nations Convention on the Law of the Sea (UNCLOS), ${ }^{1}$ rather narrowly defines what may constitute legitimate reasons for objecting to or restricting the laying of such pipelines. This may give States an incentive to make use of the legitimate grounds for such objections, including protection of the marine environment, also for the pursuance of what are in fact other policy objectives which are not in themselves recognized by UNCLOS. A somewhat cautious approach to the reasons given for restrictive measures may therefore be called for. It should also be kept in mind that the legal decisions made by the competent national authorities are reflective of how they have construed relevant international and EU law in a context of strong political and economic interests. However, this does not detract from the affected States' obligation to comply with applicable law in good faith. The fact that the construction and application of international rules by national authorities in many cases may contribute to the modification of those rules as between the parties concerned makes a thorough analysis important.

The environmental implications of submarine pipelines and related operations at sea have become particularly current by the decision of Nord Stream AG, the company owning and operating the Nord Stream pipeline, to pursue the building of further gas pipelines through the Baltic Sea. If carbon capture and storage (CCS $)^{2}$ gains traction as a large-scale climate change mitigation option that is also likely to entail a surge in demand for gas pipelines on shore are as well as offshore. There are hence good reasons for taking an interest in the ability of the law, in its different manifestations, to address

1 United Nations Convention on the Law of the Sea, 10 December 1982, 1833 U.N.T.S. 397.

2 CCS denotes a set of techniques and methods that allow $\mathrm{CO}_{2}$ generated by combustion to be sequestered and thus prevented from reaching the atmosphere. See generally B. Metz, et al. (eds), IPCC Special Report on Carbon Dioxide Capture and Storage, prepared by Working Group III of the Intergovernmental Panel on Climate Change (2005). 
environmental considerations while also having due regard to other legitimate objectives related to submarine pipelines. In the Nord Stream case various concerns had to be addressed, and preferably coordinated, across several legal systems and against the backdrop of jurisdictional rules in want of clarity. ${ }^{3}$

The intention of the present study is to elucidate the legal conditions that apply to the construction and operation of submarine pipelines and the assessments and decisions made in the particular case of Nord Stream with an emphasis on the protection of the marine environment. In this the focus will be on the way in which national authorities have applied international and EU-law and the extent to which they have thereby afforded appropriate protection to the marine environment while respecting the other legitimate uses of the seas as defined by international law. Thereby it may hopefully contribute to future efficient application, or to the orderly further evolution, of the law in this field.

One arguably essential environmental law aspect of the Nord Stream project is not covered by this study, namely the one relating to the carrying out of environmental impact assessments (EIA) in a transboundary context. The reason is that it has been eminently discussed elsewhere why the current effort will be directed towards less well researched aspects of the project. ${ }^{4}$ Issues of liability will also not be addressed, primarily because they apply ex post and are not part of the permitting procedures directly defining the conditions for a pipeline's construction and operation. ${ }^{5}$

\section{About Nord Stream}

The Nord Stream project, in its currently existing form, comprises two parallel gas pipelines (although mostly referred to here collectively as 'the pipeline') with the combined capacity to transport $55 \mathrm{bcm}$ of natural gas from Russia to Germany annually, or the equivalent of up to 26 million households' energy needs. The submarine pipelines originate in Portovaya in the Vyborg area, Russia, then pass through the EEZ of Finland and Sweden, before entering not

3 On the ambiguities of pipeline regulation under international law see e.g. J. Crowley, International and Coastal State Control over the Laying of Submarine Pipelines on the Continental Shelf - The Ekofisk-Emden Gas Pipeline, 56 Nordic Journal of International Law (1987) 39, at 40, and M. M. Roggenkamp, Petroleum Pipelines in the North Sea: Questions of Jurisdiction and Practical Status, 16 Journal of Energy \& National Resources Law. (1998) 92, at 106.

4 See T. Koivurova \& I. Pölönen, Transboundary Environmental Impact Assessment in the Case of the Baltic Sea Gas Pipeline, 25 International Journal of Marine and Coastal Law (2010) 151-181. See also S. Wolf, Unterseeische Rohrleitungen und Meeresumweltschutz: Eine völkerrechtliche Untersuchung am Beispiel der Ostsee (2011), at 323 et seq.

5 On environmental liability in the Nord Stream context see e.g. S. Romppanen, Reflections on Environmental Responsibility - With an Emphasis on the Nord Stream Pipeline in the Baltic Sea Area, Nordic Environmental Law Journal (No. 1 2010) at 23-48. Obviously, liability also has an impact on the framing and execution of a project since it affects the economic risks involved. 
only the EEZ but also the territorial waters of Denmark, and finally landing in Lubmin, near Greifswald, in Germany. ${ }^{6}$

The idea of a trans-Baltic pipeline started to materialize in the late1990s and feasibility studies of different routing options were conducted by North Transgas, a company whose major owners were OAO Gazprom ('Gazprom') and the Finnish company Fortum Oil and Gas Oy ('Fortum'). ${ }^{7}$ The studies, which considered different combinations of onshore and offshore segments, concluded that a submarine pipeline solution, similar to that eventually built, was the most feasible option for connecting Russia's natural gas fields with the central European market. The project was subsequently taken over by Gazprom due to a change of company strategy within Fortum. ${ }^{8}$

In September 2005, Gazprom, BASF AG and E.ON AG reached an agreement on the joint assumption of responsibility for the development, construction and operation of a new upstream pipeline system. The same year the North European Gas Pipeline Company was founded to plan, construct and eventually operate the pipeline. In late 2006 the company was renamed Nord Stream AG. ${ }^{9}$ The final shareholder agreement on the construction of the Nord Stream pipelines via the Baltic Sea was signed in July 2007. Unlike earlier assessed versions it did not contain a connection to Sweden due to a lack of demand in that market. ${ }^{10}$

Subsequently additional owners have been added and Nord Stream AG is now an international joint venture by a number of major energy and industrial companies with Russian Gazprom holding a majority post of 51 percent. ${ }^{11}$ The remaining 49 percent is devided between the German companies BASF SE/Wintershall Holding GmbH and E.ON Ruhrgas AG (15.5 percent each), the Dutch gas infrastructure company N.V. Nederlandse Gasunie and the French energy company GDF SUEZ S.A. (9 percent each). ${ }^{12}$ Nord Stream AG is based

6 The Nord Stream Pipeline Project, Fact Sheet, February 2013; Natural Gas: An Important Part of the Energy Mix, at “www.nord-stream.com/environment/natural-gas/” (14 August 2013). For the exact route of the Nord Stream pipelines see "www.nord-stream.com/pressinfo/images/european-gas-pipeline-system-2915/?q=\&category=115\&year=all\&page=5 \&per_page=12" (4 April 2013).

7 Koivurova \& Pölönen, supra note, 4, at 156. Already in the late 1980s the Swedish gas company Swedegas, in cooperation with the Finnish company Neste, had considered options for transportation of Russian gas to Sweden and Western Finland. Offshore routes north and south of Åland were analysed and marine surveys conducted in 1989 and 1990. Nord Stream Environmental Impact Assessment Documentation for Consultation under the Espoo Convention, Nord Stream Espoo Report, February 2009, Volume II: Chapter 1-8, at 26. On the routes surveyed in 1998 see Ibid., at 28.

8 Koivurova \& Pölönen, supra note 4, at 156 and F. Cameron, The Nord Stream Gas Pipeline Project and Its Strategic Implications: Briefing Note, European Parliament, DirectorateGeneral Internal Policies (2007), at 1.

9 Nord Stream Environmental Impact Assessment Documentation for Consultation under the Espoo Convention, supra note 7, at 21.

10 Ibid., at 34.

$1150.002 \%$ of OAO Gazprom is owned by the Russian State. Ibid., at 22.

12 'Who We Are’, at “www.nord-stream.com/about-us/” (8 March 2013). 
in Zug, Switzerland, where also the control center, from which the pipeline is monitored and operated, is situated. Nord Stream AG's total investment in the project is reported at 7.4 billion euros. ${ }^{13}$

The laying of the first pipeline began in April 2010 and transportation of gas through the line commenced in November 2011. In October 2012 gas started to flow also through the second line. ${ }^{14}$

In addition to the sea-based pipelines the overall project also comprises almost 100 kilometres of onshore pipelines that connect existing gas pipelines from Siberia to Viborg. ${ }^{15}$ There are also associated projects in which pipelines are built to increase the capacity to deliver gas from Nord Stream's landing point in Lubmin across Germany and beyond. ${ }^{16}$

In the spring of 2011 Nord Stream AG announced that it would conduct a feasibility study of options to further increase the capacity to transport natural gas from Russia to the EU through the Baltic Sea. ${ }^{17}$ Less than six months later Nord Stream AG's shareholders' committee acknowledged the outcome of the study, including the technical, environmental and financial possibility of extending the pipeline system. ${ }^{18}$

The extension project comprises construction and operation of up to two additional natural gas pipelines, each with a transport capacity of 27.5 billion cubic metres annually, the construction of which is scheduled to take place from 2016 to 2018. After Estonia rejected Nord Stream AG's application for a permit to carry out reconnaissance surveys in Estonian waters all the potential routing corridors considered go through Finnish, Swedish and Danish waters like the two existing lines. ${ }^{19}$

\section{$3 \quad$ International and EU Law Premises}

As with virtually any sea-based activity UNCLOS plays a vital role for the laying and operation of sea-based pipelines, not least by defining what

13 The Nord Stream Pipeline Project, supra note 6.

14 Nord Stream Extension Project Information Document (PID), March 2013, Document No. N-GE-PER-REP-000-PID00000-A, at 10.

15 C.E. Smith, Special Report: Pipeline construction plans continue slide despite growth in natural gas, Oil and Gas Journal (online version), 7 February 2011.

16 The most advanced project is the Ostsee Pipeline Anbindungs Leitung (OPAL), a Wintershall-Gazprom joint venture. With the capacity to transport $36 \mathrm{Bcm} / \mathrm{a}$ of gas it is the biggest natural gas pipeline in Europe and stretches from Lubmin south towards Olbernhau to interconnect with existing natural gas pipeline networks in the Czech Republic. Ibid. and A rare find: the OPAL pipeline, Pipelines International - March 2012, at "pipelines international.com/news/a_rare_find_the_opal_pipeline/067011/” (9 August 2013).

17 Nord Stream to Assess Options to Further Increase Gas Import Capacity through the Baltic Sea, Nord Stream press release, 11 May 2012.

18 Next Step in the Potential Extension of Nord Stream, Nord Stream press release, 8 October 2012.

19 Nord Stream Extension Project Information Document (PID), supra note 14, at 9. 
competences accrue to different actors within a particular area. Regional international agreements, most noticably the Convention on the Protection of the Marine Environment of the Baltic Sea ('Helsinki Convention') ${ }^{20}$ and the Convention on Environmental Impact Assessment in a Transboundary Context ('Espoo Convention') ${ }^{21}$ could also have an important impact in the specific context of the Baltic Sea. The latter, however, will not be dealt with here since the EIA procedure falls outside the ambit of this study. The former will be discussed below in the context of obligations on environmental protection.

\subsection{Issues of Jurisdiction}

As noted above UNCLOS establishes a 'legal infrastructure' by determining what competences - primarily legislative and executive jurisdiction in relation to various activities - different categories of States may exercise in different areas or maritime zones. This is not least relevant in relation to pipelines, subject as they are to a complex jurisdictional regime, based on the balancing of potentially opposing interests.

Due to the relative proximity of the coastal States there is no so-called high seas in the Baltic Sea. Any sea-based activity is thus bound to take place within one or several jurisdictional zones pertaining to adjacent coastal States, thus making the activity subject to some level of coastal State control. Simply put, the level of control is inversely related to the distance from the nearest coast, i.e. the further out at sea an activity or incident occurs the less claim to jurisdiction can be made by the coastal State. The jurisdictional zones of primary interest for the Nord Stream pipeline are the exclusive economic zone (EEZ) and the continental shelf. The point of departure for establishing these and other zones is the so-called baseline, which either equals the low-water line along the coast or, in specific circumstances, may consist of straight lines joining appropriate points seawards of the coastline such as islands. ${ }^{22}$

Save for internal waters - i.e. waters on the landward side of the baseline the jurisdictional zone closest to the land territory, both geographically and in terms of legal characteristics, is the territorial sea which stretches a maximum of 12 nautical miles seawards from the baseline. ${ }^{23}$ With the main exception of innocent passage of ships, which lacks immediate relevance for pipelines, coastal States enjoy the same rights in their territorial seas as with respect to their land territory, i.e. sovereignty. The restrictions (addressed below) imposed on coastal States with respect to the laying of pipelines on their continental shelves' do not affect the right of such States to establish conditions

20 Convention on the Protection of the Marine Environment of the Baltic Sea Area, 9 April 1992, 1507 U.N.T.S. 167.

21 Convention on Environmental Impact Assessment in a Transboundary Context, 25 February 1991, 1989 U.N.T.S. 310.

22 For the precise definition of normal and straight baselines see UNCLOS, Arts. 5 and 7.

23 UNCLOS, Art. 3. 
for cables or pipelines entering their territories or territorial seas. ${ }^{24}$ There exists no right to lay or operate pipelines in another State's territorial sea. The coastal State has far-reaching discretion as to whether it will allow such activities, and if so under what conditions.

With respect to Nord Stream the territorial sea really only has significance in the case of Denmark. The pipeline does traverse Russian and German territorial seas but since it also has landfalls in these States they already possess the most solid basis available for exercising jurisdiction. The fact that a pipeline enters a State's territorial waters does not give it any particular right to control the pipeline beyond this zone. However, such a State nonetheless enjoys considerable influence on the whole pipeline since the design and technical details tend to be the same for the whole pipeline stretch. ${ }^{25}$

With respect to Finland and Sweden the existing lines of the Nord Stream pipeline only affect their EEZ and continental shelf. The EEZ, which may stretch a maximum of 200 nautical miles from the baseline, ${ }^{26}$ has to be claimed by the coastal State, i.e. it does not exist ipso facto, or as an inevitable consequence of the existence of a coastal State. However, all the coastal States affected by the laying of the Nord Stream pipeline have claimed an EEZ, thereby causing the absence of high seas in the Baltic.

In the EEZ the coastal State does not enjoy sovereignty as such, but sovereign rights for specific purposes, namely for exploring and exploiting, conserving and managing the living as well as non-living natural resources of this zone. This applies to the waters superjacent to the seabed as well as to the seabed and its subsoil. The coastal State also has sovereign rights with regard to other activities for the economic exploitation and exploration of the zone. ${ }^{27}$ Furthermore, and of particular significance in this case, the coastal State has jurisdiction, as provided for in relevant provisions of UNCLOS, with regard to the protection and preservation of the marine environment; marine scientific research; and the establishment and use of artificial islands, installations and structures. ${ }^{28}$ Pipelines are not installations or structures in this regard but are subject to a distinct regulatory regime. ${ }^{29}$ They can, however, obviously affect the marine environment.

In the EEZ all States, and indirectly their citizens, ${ }^{30}$ enjoy with some exceptions, and subject to UNCLOS, the freedom of the high seas. This

24 Ibid., Art. 79 (4).

25 R. Lagoni, Cable and Pipeline Surveys at Sea, in H. P. Hestermeyer et al. (eds.), Coexistence, Cooperation and Solidarity: Liber Amicorum Rüdiger Wolfrum, Vol. 1 (2012) 933, at 949.

26 UNCLOS, Art. 57.

27 Ibid., Art. 56 (1) (a).

28 Ibid., Art. 56 (1) (b).

29 R. Lagoni, Pipelines, in R. Wolfrum (ed.), Max Planck Encyclopedia of Public International Law (e-resource, 2008, updated April 2011), para. 10; Wolf, supra note 4, at 191.

30 The freedom pertains to States, not individuals. But in practice the activities covered by the freedom of the high seas are overwhelmingly exercised by private parties. W. Wiese, 
freedom comprises, inter alia, freedom of navigation and overflight and of the laying of submarine cables and pipelines, but also other internationally lawful uses of the sea related to these freedoms, such as those associated with the operation of submarine cables and pipelines. Activities carried out under this freedom must be compatible with other relevant provisions of UNCLOS. ${ }^{31}$

However, like most pipelines the Nord Stream pipeline is laid on the seabed, which, at least within 200 nautical miles from the nearest baseline forms part of the continental shelf. ${ }^{32}$ Unlike the EEZ the continental shelf does not have to be claimed but exists ipso facto and $a b$ initio. ${ }^{33}$ Since the continental shelf extends seawards from the territorial sea the bottom of the EEZ will also by definition be the continental shelf of the coastal State. ${ }^{34}$ Without affecting the legal status of the superjacent waters the coastal State exercises sovereign rights over the continental shelf for the purpose of exploring it and exploiting its natural resources. ${ }^{35}$

Of paramount importance in the present context is that, according to UNCLOS, Article 79 (1), all States are entitled to lay submarine cables and pipelines on the continental shelf. Subject to its right to take reasonable measures for the exploration of the continental shelf, the exploitation of its natural resources and the prevention, reduction and control of pollution from pipelines, the coastal State may not impede the laying or maintenance of such cables or pipelines. ${ }^{36}$ It is hence not permissible for coastal States to impose restrictions on the laying or operation of submarine pipelines - provided that they do impede the laying or maintenance ${ }^{37}$ - for other reasons, such as security or energy policy considerations. ${ }^{38}$

Grenzüberschreitende Landrohrleitungen und seeverlegte Rohrleitungen im Völkerrecht (1997), at 210.

31 UNCLOS, Art. 58 (1).

32 In legal terms the continental shelf of a coastal State comprises the seabed and subsoil of the submarine areas that extend beyond its territorial sea throughout the natural prolongation of its land territory to the outer edge of the continental margin, or to a distance of 200 nautical miles from the baselines from which the breadth of the territorial sea is measured where the outer edge of the continental margin does not extend up to that distance. UNCLOS, Art. 76 (1). The continental shelf may extend even further under certain conditions which, however, are beyond the preview of this analysis.

33 Ibid., Art. 77 (3). In the words of the ICJ the continental shelf is an 'inherent right'. North Sea Continental Shelf Cases (FRG/Den.; FRG/Neth.), 1969 ICJ REP. 3 (Feb 20), para. 19.

34 As the ICJ has succinctly noted: 'Although there can be a continental shelf where there is no exclusive economic zone, there cannot be an exclusive economic zone without a corresponding continental shelf.' Continental Shelf (Libya/Malta), 1985 ICJ REP. 13 (June 3), para. 34.

35 UNCLOS, Art. 78.

36 Ibid., Art. 79 (2).

37 All States are under a general obligation to abide by the laws and regulations adopted by the coastal State for its EEZ to the extent that they are consistent with international law, particularly Part V of UNCLOS on the EZZ. Ibid., Art. 58(3).

38 Koivurova \& Pölönen, supra note 4 , at 179 . It may also be noted that climate change considerations are not covered by the definition of 'pollution' in UNCLOS, Art. 1 (1) (4). It 
In addition to circumscribing the legitimate bases for coastal State action this provision simultaneously confirms the right of every coastal State to take reasonable measures in pursuance of the three listed objectives, among them the reduction and control of pollution from pipelines. Highly significant in this regard is also that the delineation of the course for the laying of submarine pipelines on the continental shelf is subject to a requirement, in Article 79 (3), of consent by the coastal State. This enables coastal States to establish consent procedures for pipeline-laying on the continental shelf. It may be noted that no such right to have the final say on delineation is recognised by UNCLOS for submarine cables. Nonetheless, a number of States, among them Germany, have established permit requirements that apply equally to cables and pipelines. $^{39}$

The laying of pipelines is regulated in both the regimes for the EEZ (Part V) and that for the continental shelf (Part VI) in UNCLOS, and the relationship between these two has been subject to extensive discussion. ${ }^{40}$ The best view seems to be that the two regimes exist in parallel rather than one generally taking precedence or consuming the other. ${ }^{41}$ However, Article 56, in the part on the EEZ, stipulates that the coastal State's rights to exercise jurisdiction in relation, inter alia, to the protection and preservation of the marine environment shall, with respect to the seabed and subsoil, be exercised in accordance with Part VI, i.e. the specific regime for the continental shelf. In this respect a hierarchy is thus established. It should be kept in mind, however, that the coastal State's right with respect to the continental shelf does not affect the legal status of the waters above the shelf. They remain governed solely by the EEZ-regime. ${ }^{42}$ One important implication of this in the Nord Stream case is that a maintenance platform, as the one initially planned for the Swedish EEZ, is subject to the additional jurisdictional claims of the coastal State that follow from UNCLOS Part V, i.e. the regime for the EEZ.

The precise extent of the legal powers that accrue to the coastal State with respect to pipelines in its EEZ and continental shelf and its weighing up against potentially opposing legitimate interests of other States have been addressed by the present author elsewhere. ${ }^{43}$

would hence not be permissible to restrict the laying of an oil or gas pipeline due to the climate effects of fossil fuels.

39 W. Wurmnest, The Law Applicable on the Continental Shelf and in the Exclusive Economic Zone: The German Perspective, 25 Ocean Yearbook (2011), 311, at 328.

40 The main arguments are accounted for in B. Kwiatkowska, The 200 mile Exclusive Economic Zone in the New Law of the Sea (1989), at 6 et seq.

41 Ibid., at 70 with further references.

42 UNCLOS, Art. 78.

43 D. Langlet, Transboundary Transit Pipelines: Reflections on the Balancing of Rights and Interests in Light of the North Stream Project, International \& Comparative Law Quarterly 2014 (forthcoming). 


\subsection{The Legal Status of Nord Stream and its Implications}

Nord Stream AG is, as previously mentioned, based in Zug, Switzerland. There is also the control center, from which the pipelines are monitored and operated, situated. Despite its ownership structure Nord Stream AG is thus to be regarded as a national of Switzerland and subject to Swiss jurisdiction in accordance with the nationality principle. ${ }^{44}$ This also makes Switzerland competent to exercise diplomatic protection (ius protectionis) with respect to the company. ${ }^{45}$ The exercise of diplomatic protection by any other State, such as Russia, would hardly be consistent with international law even though Nord Stream AG is a consortium with a Russian majority shareholder. It is well established that the primary criterion for justifying diplomatic protection on behalf of a company is incorporation. ${ }^{46}$ In its Draft Articles on Diplomatic Protection the International Law Commission (ILC) provides an alternative definition of a company's nationality. If, namely, a corporation is controlled by nationals of another State than that of incorporation such other State may be regarded as the State of nationality. However, this only applies if the company has no substantial business activities in the State of incorporation, and the seat of management and the financial control of the corporation are both located in the other State. ${ }^{47}$ It should thus be clear that the mere ownership of shares in a company by natural or legal persons in any one State does not suffice to justify the exercise of diplomatic protection by that State. ${ }^{48}$

However, it is conceivable in this case that either Germany or Russia could also bring a legitimate international challenge against a decision or other act

44 Roggenkamp, supra note 3, at 98. This is confirmed by the Finnish Government's decision regarding the laying of the pipeline in the Finnish EEZ which explicitly refers to Switzerland as the applicant's domicile and notes that the country is party to UNCLOS. 'Consent to Exploit Finland's Exclusive Economic Zone' (5 November 5, 2009) 678/601/2009 (Unofficial translation provided by the Ministry of Employment and the Economy), at "www.envir.ee/orb.aw/class=file/action=preview/id=1105159/Soome_val_ luba_NS.pdf” (visited 8 June 2013), at 22.

45 The International Law Commission (ILC) defines diplomatic protection as 'the invocation by a State, through diplomatic action or other means of peaceful settlement, of the responsibility of another State for an injury caused by an internationally wrongful act of that State to a natural or legal person that is a national of the former State with a view to the implementation of such responsibility.' 'ILC:s Draft Articles on Diplomatic Protection', Official Records of the General Assembly, Sixty-first Session, Supplement No. 10 (A/61/10), Art. 1. Although establishing the nationality of a company for the purpose of diplomatic protection is not an entirely straightforward operation there should be little doubt that incorporation, headquarters and technical operation center in Switzerland suffices to establish a requisite connection. See on this matter I. Brownlie, Principles of Public International Law (6th ed. 2003), at 465.

46 Draft Articles on Diplomatic Protection, supra note 45, para. 32.

47 Ibid., Art. 9.

48 This also tallies with the ICJ's finding in Barcelona Traction that with respect to limited liability companies whose capital is represented by shares the shareholders are separated from the company by numerous barriers and cannot be identified with it. Barcelona Traction case (Belgium v Spain) (Second Phase) ICJ Rep 1970, 3, at 35. 
that allegedly constituted an impediment to the laying or operation of pipelines on the continental shelf in contravention of international law. It would then not be a matter of diplomatic protection on behalf of a national, but of action taken for the protection of an unmediated national interest.

Establishing who is entitled to invoke the responsibility of a State as a consequence of its transgression of an international obligation, e.g. by commencing proceedings before an international court, can be a challenging endeavor and will rely on the specific circumstances of each case. ${ }^{49}$ With respect to UNCLOS, Article 79 it should be evident that we are not dealing with an obligation erga omnes, i.e. one owed to the community of States as a whole. ${ }^{50}$ Nor would it be reasonable to consider all parties to UNCLOS, or for that matter any predetermined subgroup of parties, as being entitled to invoke such responsibility. ${ }^{51}$ However, with respect to an impediment to the construction or operation of a pipeline a State at the sending or receiving end of it could arguably be deemed 'specifically affected' and thereby qualify as an 'injured State' as defined by the ILS's Draft Articles. ${ }^{52}$ Not least if unimpeded

49 Among other complicating factors the ICL's 'Draft Articles on Responsibility of States for Internationally Wrongful Acts' makes a distinction between an injured State and those other States who, despite not qualifying as injured, nonetheless have a legal interest in invoking responsibility (but not in claiming compensation). 'Draft Articles on Responsibility of States for Internationally Wrongful Acts', in Report of the International Law Commission on the Work of Its Fifty-third Session 43, UN GAOR, 56th Sess., Supp. No. 10, UN Doc. A/56/10 (2001) 615, Articles 42 and 48.

50 The ICJ has famously found that obligations owed towards the international community as a whole 'derive, for example, in contemporary international law, from the outlawing of acts of aggression and of genocide, as also from the principles and rules concerning the basic rights of the human person, including protection from slavery and racial discrimination'. Barcelona Traction case, supra note 48, at para. 33. Even though such norms could also be found in areas of law pertaining to economic activities it is highly unlikely that the freedom reflected in UNCLOS, Art. 79 would qualify to this category. On the development and role of erga omnes obligations see e.g. E. De Wet, The International Constitutional Order, 55 International and Comparative Law Quarterly (2006), 51-76.

51 Merely a general interest in preventing the erosion of an international obligation does not justify the invocation of responsibility. Unless a State is individually injured it must be able to rely on an obligation owed to a group of States, including that State, established for the protection of a collective interest of that group. (Draft Articles, Art. 48 1. (a).). Examples of such obligations might be those that concern the environment or security of a region. Comment to Art. 48 1. (a) Ibid., at 126. The finding of the Permanent Court of International Justice (PCIJ) in the Wimbledon case, that the Applicant States had 'a clear interest' in the execution of the provisions of the Peace Treaty of Versailles relating to free passage through the Kiel Canal merely because they all possessed fleets and merchant vessels flying their respective flags has sometimes been taken to imply a very broad understanding of legal interest. However, as showed i.a. by Hutchinson, this finding must be read in the context of the specific nature of the Peace Treaty of Versailles, most notably its Art. 386, and does thus not easily lend itself to generalizations. D. N. Hutchinson, 'Solidarity and Breaches of Multilateral Treaties’, 59 British Yearbook of International Law (1988), 151215, at 180 et. seq. On the particular problems associated with so called third State remedies see J. I. Charney, Third State Remedies in International Law, 10 Michigan Journal of International Law (1989), 57.

52 Draft Articles on Responsibility of States for Internationally Wrongful Acts, supra note 49, Art. 42. 
transport through the pipeline has significant financial and (energy) security implications for such a State. ${ }^{53}$ As usual the conclusion would be contingent on the specific circumstances of the case. And as always with international law it would also be necessary to establish a basis for jurisdiction with respect to any particular court or tribunal if it were to be seized with the matter. No international legal action was taken by any State as a result of the applications submitted by Nord Stream AG, and the subsequent decisions made, regarding the original two lines of the Nord Stream pipeline.

In this context it may be noted that Switzerland as well as all the States on whose territory or through whose maritime zones the Nord Stream pipeline passes are parties to UNCLOS. However, Switzerland became a party only in May 2009, just a few months before decisions were made by the States concerned on Nord Stream AG's permit applications. UNCLOS was thus, by a close margin, applicable and any discussion on whether relevant provisions of the Convention would be applicable as customary law became superfluous.

The Nord Stream project stands out from most other transboundery submarine pipeline projects by not being governed by any agreement between the States concerned, including the so-called sending and receiving (Russia and Germany) States. ${ }^{54}$ Accordingly, there is no specific regulation of inter alia the operation of the pipeline, the settlement of any disputes that may arise, or specifying how jurisdiction is to be exercised beyond the territorial seas. Instead pertinent multilateral agreements and general international law apply. ${ }^{55}$

\subsection{Environmental Protection}

UNCLOS is not only about jurisdiction, or defining spheres of competence. It also sets out substantive rules in many areas, including protection of the marine environment. The overall obligation incumbent on States in this respect is 'to protect and preserve the marine environment. ${ }^{56}$ Slightly more specific is the obligation in Article 194 (2) on all States to take 'all measures necessary to

53 In order to be 'specifically affected' a State must be 'affected by the breach in a way which distinguishes it from the generality of other States to which the obligation is owed' Commentary to Art. 42, 'Draft Articles on Responsibility of States for Internationally Wrongful Acts', supra note 49, at 119. Particularly with an already built pipeline, but also with respect to one that has reached an advanced planning stage it should not be hard to show that its construction and operation affects the sending and receiving States in a qualified manner.

54 S. Vinogradov, Challenges of Nord Stream: Streamlining International Legal Frameworks and Regimes for Submarine Pipelines, 52 German Yearbook of International Law (2009), at 257. This may be compared to oil and gas pipelines in the North Sea, which are mostly subject to bilateral treaties between 'sending' and 'receiving' States. Roggenkamp, supra note 3, at 100. See, as an example, the 1973 Agreement Relating to the Transmission of Petroleum by Pipeline from the Ekofisk Field and Neighbouring Areas to the United Kingdom (1973 Ekofisk Treaty).

55 On the application of general principles of jurisdiction to submarine pipelines, see Roggenkamp, supra note 3, at 96 et seq.

56 UNCLOS, Art. 192. 
ensure that activities under their jurisdiction or control are so conducted as not to cause damage by pollution to other States and their environment'. A further relevant provision may be found in Article 208, stipulating that coastal States shall adopt laws and regulations to prevent, reduce and control pollution of the marine environment arising from or in connection with seabed activities subject to their jurisdiction. It is also made clear that States shall take other measures as may be necessary to prevent, reduce and control such pollution. ${ }^{57}$ However, these provisions are not very detailed and may in many respects rather serve as a link to regional or sectoral agreements than as operative rules for specific activities. ${ }^{58}$

The fact that the Baltic Sea is a so-called semi-enclosed sea entails a particular obligation of cooperation for the States bordering the sea. ${ }^{59}$ These States are expected to cooperate with each other in the exercise of their rights and in the performance of their duties under UNCLOS, e.g. by endeavouring to coordinate the implementation of their rights and duties with respect to the protection and preservation of the marine environment. ${ }^{60}$ Regional agreements such as the Helsinki Convention offer forums for such cooperation, as well as enable the general provisions of UNCLOS to be somewhat concretized. ${ }^{61}$

Submarine pipelines are not explicitly regulated in the Helsinki Convention. It does, however, establish some 'fundamental principles and obligations' of potential relevance to the environmental effects of pipelines. Among these is an obligation to apply the precautionary principle by taking preventive measures when there is reason to assume that substances or energy introduced, directly or indirectly, into the marine environment may create hazards to human health, harm living resources and marine ecosystems, damage amenities or interfere with other legitimate uses of the sea even when there is no conclusive evidence of a causal relationship between inputs and their alleged effects. ${ }^{62}$ The parties are also required to individually or jointly take all appropriate legislative, administrative or other relevant measures to prevent and eliminate pollution in order to promote the ecological restoration of the Baltic Sea Area and the preservation of its ecological balance. ${ }^{63}$

57 UNCLOS, Art. 208 (2).

58 P. W. Birnie and A. E. Boyle, International Law and the Environment, (2002), at 353.

59 The Baltic Sea qualifies as semi-enclosed both because it is 'surrounded by two or more States and connected to another sea or the ocean by a narrow outlet' and since it consists 'entirely or primarily of the territorial seas and exclusive economic zones of two or more coastal States' according to UNCLOS, Art. 122.

60 UNCLOS, Art. 123.

61 Although the environmental impact assessment is not addressed here it may be noted that the Finnish Government refers to its participation in the international EIA under the Espoo Convention as its way to dispose of the obligation to cooperate that pertains to States bordering a semi-enclosed sea like the Baltic Sea. 'Consent to Exploit Finland's Exclusive Economic Zone', supra note 44, at 23.

62 Helsinki Convention, Art. 3 (2).

63 Ibid., Art. 3 (1). 
The Baltic Sea Action Plan, a non-binding instrument adopted by representatives of the Helsinki Convention Member States in 2007 with the aim of restoring the good ecological status of the Baltic marine environment by 2021, makes reference to pipelines in the context of threats from offshore installations. The rising number of such installations are identified as putting increasing pressure on the Baltic Sea ecosystem and any environmentally significant adverse impacts should be prevented, reduced or offset as fully as possible. ${ }^{64}$

To the extent that a regional agreement imposes additional obligations compared to UNCLOS it is necessary to inquire whether these obligations are indeed applicable to all relevant actors. If not, an incongruous situation is likely to ensue in which those actors associated with a State party to the regional agreement can be made subject to additional obligations compared to those associated with nonparties. This follows from the principle that States may generally derogate from international obligations - such as the obligation not to impede the laying and operation of pipelines on the continental shelf on other grounds than those listed in UNCLOS, Article 79 - as between themselves but not with effect to third parties. ${ }^{65}$

All the coastal States of the Baltic Sea are parties to the Helsinki Convention. Switzerland, however, is not a party. This Convention can thus not be used to legitimize obligations imposed on a Swiss national if they are not consistent with UNCLOS. However, unless international agreements are directly applicable before domestic courts and agencies, which is generally not the case in the States concerned here, a challenge against such an obligation would have to be brought at the international level, i.e. in this case typically by Switzerland exercising its right to ius protectionis against the State responsible for this transgression of international law.

In light of the above analysis it may be concluded that coastal States have a responsibility to consider the environmental consequences of pipelines even when the laying and operation of those occur outside of their sovereign control but where they still exercise jurisdiction and thus (some level of) control, e.g. on their continental shelf. ${ }^{66}$ Coastal States are thus obliged to take necessary measures, within their competence under UNCLOS Article 79, to guarantee that pipelines do not cause harm to the marine environment beyond what is

64 HELCOM Baltic Sea Action Plan, adopted on 15 November 2007 in Krakow, Poland, by the HELCOM Extraordinary Ministerial Meeting, Chapter on Maritime Activities.

65 See e.g. Vienna Convention on the Law of Treaties, 23 May 1969, 1155 U.N.T.S. 331, Art. 41. This option applies as long as the obligation in question does not have status of jus cogens. Ibid., Art. 53.

66 This is reflected e.g. in the following statement in the Swedish permit decision: 'The rules of the UN Convention on the Law of the Sea involve a clear and general duty on all States to protect and conserve the marine environment, with special responsibility by the coastal State for preventing any harmful environmental impact in its economic zone and on its continental shelf. This must be taken into account in examining the Company's application.' Government Decision No 15, Nov. 5, 2009, N2008/147/FIN, at 16. 
tolerated under applicable international law. ${ }^{67}$ Restrictions on pipelines above those mandated by UNCLOS Article 79 may be imposed based on bilateral or regional agreements.

As will be noted below, in the section on national permit procedures, EU law played a limited role, at least explicitly, in the legal assessments carried out by the competent national authorities. Save for legal acts related to EIA the pieces of EU legislation of greatest significance for the licensing of submarine pipelines are the so-called Habitats Directive, ${ }^{68}$ and the associated Birds Directive, ${ }^{69}$ which establish the system of protected areas known as Natura 2000.

While the applicability of domestic law, and thus of implemented EU-law, in the EEZ of a particular EU Member State may be a complex issue, it has been clearly established that Member States are obliged to implement the Habitats Directive not only in relation to their territorial waters, but also on the continental shelf and the EEZ. ${ }^{70}$

4 Policy Context

The economic and political dimensions of the Nord Stream project have been subject to extensive discussion elsewhere which need not be repeated here. ${ }^{71}$ However, some brief reflections on these dimensions will inform the subsequent legal discussion.

The objections raised by different stakeholders towards the Nord Stream project have had multiple, and often mixed, bases and rationales. A fundamental distinction, though not necessarily an easy one to make, is between concerns pertaining to protection of the environment, and those relating to other interests. However, a more informative, though less neat, taxonomy can be achieved by distinguishing between objections relating to: 1 . The direct effects of the pipelines' physical presence, including their laying and operation; 2. Other consequences of the route chosen for the pipelines; and 3. General effects of building large-scale infrastructure for gas exports from Russia to western and central Europe not tied to a specific route.

67 Wiese refers to the 'Ordnungsfunktion' of the coastal State, to describe its responsibility to take measures to prevent or reduce pollution from activities under its jurisdiction. Wiese, supra note 30 , at 230.

68 Council Directive 92/43/EEC of 21 May 1992 on the conservation of natural habitats and of wild fauna and flora, [1992] OJ L206/7 (Habitat Directive).

69 Directive 2009/147/EG of the European Parliament and the Council of 30 November 2009 on the conservation of wild birds, OJ 26.1.2010 L20/7 (a codified version of Council Directive 79/409/EEC of 2 April 1979 as subsequently modified).

70 Case C-6/04, Commission v. UK [2005] ECR 1-9017, paras. 115-117.

71 See e.g. B. Solum Whist, Nord Stream: Not Just a Pipeline, FNI Report 15/2008 (2008); R. Götz, The Nord Stream Pipeline: The Energy Policy Background, in 52 German Yearbook of International Law (2009) 233; H. Smith, Russian foreign policy and energy: the case of the Nord Stream gas pipeline, in P. Aalto. (red.), Russia's Energy Policies: National, Interregional and Global Levels [e-book] Edward Elgar Publishing (2012). 
Addressing these in reverse order the major general objection to the construction of large gas pipelines from Russia to Germany has concerned energy (and thus national) sequrity. Potential environmental objections based on the lock-in effects of capital intensive infrastructure for fossil fuel transport seem laregely to have been defeted by the fact that natural (fossil) gas-fired power plants generate roughly 50 percent less carbon dioxide than do coalfired power plants, making natural gas the least climate harmful fossil fuel. ${ }^{72}$ In 2008 the European Parliament even identified the growing contribution of natural gas to the energy balance in Europe as 'the major single source of reduction of carbon dioxide $\left(\mathrm{CO}_{2}\right)$ emissions. ${ }^{73}$ In line with this Greenpeace has not opposed Nord Stream from a climate change perspective. ${ }^{74}$ Natural gas is also often touted as a bridge between an economy based on fossil fuel and one based on renewables. However, this does not rule out that investments in gas infrastructure may impede the transition to a truly low-carbon economy.

As to security a fundamental concern has been that Germany and other European countries make themselves increasingly dependent upon Russia for their energy supplies. While Nord Stream AG is anxious to describe Russia as a reliable provider, ${ }^{75}$ others emphasize the Russian government's propensity to view gas exports as a foreign policy instrument. ${ }^{76}$ The picture is complex and involves dimensions of control as well as interdependence. The EU is actively pursuing diversification of energy supply, including by promoting renewables and the building of liquefied natural gas (LGN) terminals. ${ }^{77}$ Another important, but troubled, element of this diversification strategy is the so called 'southern gas corridor' intended to transport natural gas from the Caspian Sea-region to the EU. ${ }^{78}$ Although Russia will continue to have a dominant position in

72 Natural Gas: An Important Part of the Energy Mix, at "www.nord-stream.com/ environment/natural-gas/” (2013-08-14).

73 'Environmental impact of the planned gas pipeline in the Baltic Sea', European Parliament resolution of 8 July 2008 on the environmental impact of the planned gas pipeline in the Baltic Sea to link up Russia and Germany (Petitions 0614/2007 and 0952/2006), P6_TA(2008)0336, para. H. The Finnish Government also referred to the project as being 'in accordance with the common European objective of increasing the use of more sustainable forms of energy, regarding both the energy source and the method of transfer'. 'Consent to Exploit Finland’s Exclusive Economic Zone', supra note 44, at 30.

74 Nord Stream Pipeline Poses Dilemmas for Environmentalists, Deutsche Welle, 07.11.2011, at http://www.dw.de/about-dw/who-we-are/s-3325 (2013-08-14).

75 See e.g. Nord Stream Extension Project Information Document (PID), supra note 14, at 14.

76 K. Hober, Law and Policy in the Russian Oil and Gas Sector, 27 Journal of Energy and Natural Resources Law (2009), 420-444.

77 On security of energy supply and international cooperation, see The EU Energy Policy: Engaging with Partners beyond Our Borders, Communication from the Commission, COM (2011) 539 final, at 5-6.

78 More precisely 'The Southern Gas Corridor' is jargon for various competing projects to bring gas from the Azerbaijan offshore Shah Deniz II field to EU customers. It is seen as a way to decrease EU's dependence on Russia as supplier of natural gas and as an alternative to the so called 'South Stream' pipeline, intended to transport gas from southern Russia through the Black Sea to Bulgaria and further to Greece, Italy and Austria. 
Europe's energy supply for some time that doesn't necessarily translate into a readily available instrument of political coercion, particularly not in relation to large economies like Germany. ${ }^{79}$

Despite these misgivings the Nord Stream project has been included on the European Union (EU) list of Trans-European Energy Network Guidelines (TEN-E) and designated a 'project of European interest', ${ }^{80}$ reflecting its contribution to meeting Europe's increasing demand for natural gas. However, the EU has played a very minor role in the development of the project, to the regret of the European Parliament. ${ }^{81}$ But although Nord Stream has sometimes been perceived as a bilateral German-Russian deal the gas should benefit several other countries as well. Gazprom has signed long-term contracts to supply gas through the Nord Stream pipeline inter alia to Denmark, France, the Netherlands and the UK. ${ }^{82}$

Stronger sentiments have been spurred not by the pipelines as such but by the route chosen. The land-based gas pipelines connecting Russia with Western European gas markets have been affected by repeated controversies between Russia and transit States. ${ }^{83}$ Thus it is not surprising that a sea-based solution, which effectively circumvents potential transit States, ${ }^{84}$ has an economic as well as a strategic appeal to gas exporting and -importing countries alike. Partcularly in Poland this circumvention has evoked dark historical connotations, ${ }^{85}$ while alledgedly also deminishing the country's political clout and raising fears that it will become more exposed to Russian pressure. ${ }^{86}$ While Nord Stream AG asserts that a sea-based solution was both less costly and better for the environment than a land-based one it has also repeatedly referred

79 K. Smith Stegen, Deconstructing the "energy weapon": Russia's threat to Europe as a case study, 39 Energy Policy (2011), 6505-6513, at 6511.

80 Decision No 1364/2006/EC laying down guidelines for trans-European energy networks and repealing Decision 96/391/EC and Decision No 1229/2003/EC, [2006] OJ L 262/1, Art. 8. A main priority for the EU with respect to trans-European gas networks is to develop natural gas networks in order to meet the EU's natural gas consumption needs and to control its natural gas supply systems. Ibid., Art. 4 (3).

81 Environmental impact of the planned gas pipeline in the Baltic Sea, supra note 73, para. 6; Smith, supra note 71 , at 120 .

82 Smith, supra note 71 , at 121.

83 See e.g. Russia shuts off gas to Ukraine, BBC NEWS (1 January 2009), at “news.bbc.co.uk/2/hi/europe/7806870.stm” (10 June 2013).

84 Existing land-based pipelines from Russia to Western Europe go either through the Ukraine (Soyuz and Brotherhood) or Belarus and Poland (Yamal).

85 The then Polish defence minister Sikorski even said in 2006 that the project echoed the 1939 Molotov-Ribbentrop Pact (in which the territories of several European countries, among them Poland, were divided into Nazi-German and Soviet spheres of influence just before the outbreak of WWII), Nord Stream 'a waste of money' says Poland, EURACTIV (11 January 2010, updated 31 August 2011), at http://www.euractiv.com/europes-east/nordstream-waste-money-poland-news-223390 (visited 7 March 2013).

86 I. Gawlowicz \& P. Laski, Russian-German North Gas Pipeline in View of Public International Law 28 Polish Yearbook of International Law (2006-2008), 152, at 162. 
to the benefits of disposing with transit States. ${ }^{87}$ Nord Stream AG has e.g. described the Nord Stream pipeline system and its planned extension as offering a natural gas connection 'free from non-technical risks and free of interference of a commercial or non-commercial nature by third parties. ${ }^{\text {, }} 8$

Strong opposition has also been voiced in Estonia, although for partly different reasons. ${ }^{89}$ In that case, however, it resulted in the rejection by the Estonian government of applications by Nord Stream AG to survey the sea-bed in preparation for a potential routing through Estonian waters. The primary reasons cited were national interests in the EEZ and that surveys would give information about Estonia's natural resources and their possible use. ${ }^{90} \mathrm{~A}$ similar response was given to a new application for sea-bed surveys in $2012 .^{91}$ Since surveying the seabed is an indispensable part of the planning and construction of a pipeline this meant that the Estonian EEZ would not be available to Nord Stream AG. ${ }^{92}$

Of the Baltic Sea coastal States not affected by a legacy of direct Soviet dominance during the days of the Warsaw pact the strongest objections to the routing were heard in Sweden. In this case the presence of the pipelines in the Swedish EEZ was, at least initially, viewed primarily as a military-strategic problem since they could allegedly both motivate Russian naval presence in the Swedish EEZ and be used for intelligence gathering. ${ }^{93}$ These fears were at least partially assuaged by Nord Stream AG's decision in early 2008 to dispense with a planned maintenance platform in Sweden's EEZ. ${ }^{94}$ A number of

87 On the environmental aspects of an 'overland pipeline' see the brief statement in 'Nord Stream Environmental Impact Assessment (EIA) Documentation for Consultation under the Espoo Convention', supra note 7, at 19.

88 Nord Stream Extension Project Information Document (PID), supra note 14, at 15.

89 Solum Whist, supra note 71; Götz, supra note 71; S. Vinogradov, Challenges of Nord Stream: Streamlining International Legal Frameworks and Regimes for Submarine Pipelines, 52 German Yearbook of International Law (2009), 30.

90 The Government did not agree to issue a permit for the survey application, Government Communication Unit, 20 September 2007, at "valitsus.ee/et/uudised/pressiteated/ keskkonnaministeerium/13572" (2013-08-15).

91 Cabinet meeting decides to deny Nord Stream AG's request to conduct marine investigations in Estonia's exclusive economic zone, Government Communication Unit (6 December 2012), “valitsus.ee/et/uudised/pressiteated/majandus-ja-kommunikatsiooni ministeerium/73717” (visited 7 March 2013).

92 The main purpose of such surveys is to identify a suitable pipeline route, i.e. a route that will minimize the risk for harm to the future pipeline, and indirectly harm to the environment and human activities in the vicinity of the pipeline, and avoid conflicts with other uses of the seabed. Lagoni, supra note 25, at 933.

93 Solum Whist, supra note 71, at 30; R. L. Larsson, Nord Stream, Sweden and Baltic Sea Security, Swedish Defense Research Agency (FOI), March 2007, FOI-R--2251-SE, at 3537.

94 U. Izundu, Nord Stream cancels maintenance platform plans, Oil \& Gas Journal Online Articles, 9 April 2008, at “www.ogj.com/articles/2008/04/nord-stream-cancels-maintenance -platform-plans.html” (2013-08-12). 
prominent politicians described the project as having security implications or as not being in Sweden's interest. ${ }^{95}$

When it comes to the immediate and physical consequences of the pipelines' construction and operation the major concerns have been environmental. ${ }^{96}$ Fears about the environmental harm that the project could cause, particularly during the construction phase, have featured in the debate in all the affected countries and also been voiced by the EU. ${ }^{97}$ Among the environmental impacts discussed have been the effects on the marine benthic fauna of sediment dispersed by the levelling of the seabed in preparation of the laying of the pipelie; the effect of noice caused by the construction work on fish and marine mammals; and different kinds of disturbances to protected marine areas, including some Natura 2000 sites. $^{98}$

A related worry has been the high incidence of both chemical and conventional munitions in the Baltic Sea. The former comprises approximately 40,000 tonnes of primarily German chemical warfare agents that were intentionally dumped after World War II. The latter includes an estimated 35,000 mines in the Gulf of Finland alone deployed by various navies. ${ }^{99}$

Unlike the different economic and security dimensions of the project the potential environmental effects have been subject to formal impact assessment under both international and EU-law and are being monitored continuously. ${ }^{100}$ We will return to the environmental consequences, and the mitigative action taken, in more detail in connection with the national permit procedures to which we now turn our attention.

95 Nord Stream unleashes criticism in Sweden, Finland, 6 November 2009, Energy Daily, at "www.energy-daily.com/reports/Nord_Stream_unleashes_criticism_in_Sweden_Finland _999.html” (2013-08-15); Odenberg: Gasledning säkerhetsfråga, Tidningarnas Telegrambyrå, 4 September 2007, at 1.

96 There has also been some concerns relating e.g. to the impact on commercial fishing.

97 'Environmental impact of the planned gas pipeline in the Baltic Sea', European Parliament resolution, supra note 73.

98 R. Pelkonen, \& J. Jantunen, The Nord Stream Gas Pipeline Project: Environmental Issues, Note, European Parliament, Policy Department C - Citizens' Rights and Constitutional Affairs, 2007.

99 Nord Stream Environmental Impact Assessment Documentation for Consultation under the Espoo Convention, Nord Stream Espoo Report: Key Issue Paper Munitions: Conventional and Chemical, February 2009, available at "www.nord-stream.com/press-info/library/ ?pk=62” (2013-08-16).

100 See e.g. Nord Stream Environmental Impact Assessment (EIA) Documentation for Consultation under the Espoo Convention, Nord Stream Espoo Report: Non-Technical Summary, February 2009; and Results of Environmental and Socio-economic Monitoring 2011, Nord Stream Project, September 2012, Document-No. G-PE-PER-MON-10008020000, both available at “www.nord-stream.com/press-info/library/” (2013-08-14). 


\section{The Permit Procedures}

A transboundary environmental impact assessment was initiated in November 2006 when Nord Stream AG submitted a Project Information Document on the planned pipeline to the authorities of Finland, Sweden, Denmark, Germany and Russia in accordance with the Espoo Convention. ${ }^{101}$ Applications for permission to lay the pipeline according to the proposed route were subsequently submitted to the competent authorities in those same States. In the following an overview is given of the legislative context and procedures applicable to the assessment of those applications in each State. This is followed by a thematic discussion on provisions of particular interest that occur in one or more of the national permits. Issues pertaining to maritime safety addressed in the permits are not commented upon here. The order in which the national procedures are assessed follows the flow of the gas, i.e. commencing with Russia and ending with Germany.

\subsection{Russia}

The Russian application was made to the Federal Service for Environmental Management Supervision (RosPrirodNadzor) and assed primarily according to the Federal Law On the Continental Shelf of the Russian Federation, ${ }^{102}$ and the Law On Internal Seawaters, Territorial Sea and Contiguous Zone of the Russian Federation. ${ }^{103}$

The permit is considerably shorter than those issued by the other competent national authorities. In addition to generally requiring compliance with certain domestic laws and the recommendations by the Expert Committee of the State Environmental Review Board the permit refers generally to an obligation incumbent upon the applicant to carry out the works in compliance with the norms of international law. It is specified that sewage water and wastes from

101 Nord Stream Environmental Impact Assessment Documentation for Consultation under the Espoo Convention, supra note 7, at 67.

102 Federal Law No. 187-FZ, dd. November 30, 1995, On the Continental Shelf of the Russian Federation.

103 Federal Law No. 155-FZ, dd. July 31, 1998, On Internal Seawaters, Territorial Sea and Contiguous Zone of the Russian Federation. Also relevant were certain Government Resolutions, notably the Resolution of the Government of the Russian Federation No. 68, dd. January 26, 2000, On Approval of the Procedures of Laying Submarine Cables and Pipelines in Internal Seawaters and Territorial Sea of the Russian Federation. The application was also assessed as to its compliance with Resolution of the Government of the Russian Federation No. 400, dated 30.07.2004, On Approval of the Provision on the Federal Service for Environmental Management Supervision and Amendments to the Russian Federation Government Resolution dated July 22, 2004 No. 370, and Administrative Regulation approved by Order of the Ministry of Natural Resources of Russia No. 322, dated 10.12.2007. On Issuing a Permit for Laying the Nord Stream Gas Pipeline (Russian Sector) in the Baltic Sea, 18.12.2009 No. VK-10-35/8882. 
ships should be disposed of in accordance with MARPOL 73/78. ${ }^{104}$ Notably the permit also requires the applicant to ensure minimum possible impact of the works on marine biological resources and their environment. ${ }^{105}$

\subsection{Finland}

In Finland the laying of pipelines on the continental shelf entails a two-pronged permit procedure. Nord Stream AG submitted one application to the Ministry of Employment and the Economy, to be assessed according to the Act on the Exclusive Economic Zone of Finland and an attendant Government decree, ${ }^{106}$ and a second application to a regional administrative body, ${ }^{107}$ to obtain a construction permit in accordance with the Water Act. ${ }^{108}$

The Finnish government, through the Ministry of Employment and the Economy, granted its consent in November 2009 for a period of 50 years. ${ }^{109}$ First among the conditions set out is that the project should be implemented in conformity with the precautionary principle. ${ }^{110}$ No definition of precaution or guidance as to how this is to be implemented in practice is given. More straightforwardly it is also established that the applicant must use a dynamically positioned pipe-laying vessel in certain parts of the EEZ. ${ }^{111}$

In the reasons given for the consent it is noted that neither UNCLOS nor the Finnish EEZ Act define specific criteria for granting or withholding consent to the laying of pipelines. Both instruments mention environmental protection, conservation and care as well as the economic exploitation of the EEZ as rights of the coastal State. Against this backdrop the conclusion is made that 'in the assessment, it is essential that the impacts of the project on the environment, maritime safety, and its impacts on other projects, possible damage to third parties and matters relating to the security of energy supply, are weighed up. Other States' opinions on these matters are also relevant.' 112 'Security of

104 International Convention for the Prevention of Pollution from Ships, 2 November 1973, 1340 U.N.T.S. 184, as amended by the Protocol of 17 February 1978.

105 Decision by the Federal Service for Environmental Management Supervision On Issuing a Permit for Laying the Nord Stream Gas Pipeline (Russian Sector) in the Baltic Sea, 18.12.2009 No. VK-10-35/8882.

106 Act on the Exclusive Economic Zone of Finland (1058/2004); Government Decree on the Finnish Exclusive Economic Zone (1073/2004).

107 The Western Finland Environmental Permit Authority, which was first seized with the issue, was closed down in the course of the procedure and was superseded by The Southern Finland Regional State Administrative Agency.

108 Water Act (264/1961).

109 Consent to Exploit Finland's Exclusive Economic Zone, supra note 44, at 26.

110 Ibid.

111 Use of a dynamically positioned vessel, rather than one positioned by means of anchors, reduces the need for munitions clearance, and reduces the release of harmful substances and nutrients as well as harm to sensitive sites on the seabed.

112 Consent to Exploit Finland's Exclusive Economic Zone, supra note 44, at 28. 
energy supply' is also listed as a specific item to be taken into account in the 'balancing of interests'. In this regard it is concluded that the project has no direct impact on the security of energy supply in Finland but is in accordance with the common European objective of increasing the use of more sustainable forms of energy and that the implementation of the project would thus also be relevant to Finland. ${ }^{113}$

As to Natura 2000 sites no significant impact or changes are expected to affect the conservational values of any existing or planned such areas due to the distance between the pipeline route and those sites ( $3-30$ kilometers). ${ }^{114}$

The construction permit according to the Finnish Water Act, issued in early 2010, in several respects echoes the one issued by the government a few months prior. The construction permit refers to the use of a dynamically positioned vessel and to the obligation to carry out the works so that it causes minimal harm to the marine environment and its use. ${ }^{115}$ More noteworthy is perhaps an obligation to collect waste resulting from the pipeline installation and deliver it for handling or utilization onshore. The amount of waste and the delivery locations must be recorded. ${ }^{116}$

The construction permit was appealed by some Estonian environmental NGOs asserting, inter alia, that the permit was based on insufficient and incorrect information and calling for an independent expert assessment. The NGOs were granted standing but were unsuccessful on substance since the permit was eventually upheld by the Supreme Administrative Court. ${ }^{117}$

\subsection{Sweden}

In Sweden an application for the construction of a pipeline on the continental shelf is assessed by the Government in accordance with the Continental Shelf Act. ${ }^{118}$ Initially, however, Nord Stream AG applied not only for permission to construct the pipeline as such but also a maintenance platform which would constitute a structure in the EEZ and trigger rules on that area, including the Swedish Act on the Exclusive Economic Zone. ${ }^{119}$ That would vest the government with a wide discretion. ${ }^{120}$

The application was deemed insufficient in several respects and the applicant was requested to provide inter alia 'a detailed description of the purpose of the project and alternative routes for the entire route of the

113 Ibid., at 30.

114 Ibid., at 31.

115 Water Permit, Southern Finland Regional State Administrative Agency, Decision 4/2010/4, 12 February 2010, at 116.

116 Ibid., at 117.

117 Decision by the Supreme Administrative Court, June 22, 2011, No 4324/1/10.

118 Continental Shelf Act (1966:314).

119 Swedish Exclusive Economic Zone Act (1992:1140).

120 Ibid., Section 5. 
pipelines, alternative locations for the service platform and the no action alternative' as well as detailed and in-depth documentation regarding the platform. ${ }^{121}$

Due to the ensuing debate in Sweden regarding environmental, fisheries and security concerns relating to the platform Nord Stream AG withdrew the platform application in 2008 and opted instead for a maintenance system based on deployment of intelligent pipeline inspection gauges, so called 'pigs'. ${ }^{122}$

After supplementation of the remaining application a permit was granted in November 2009. Among the conditions stipulated mention should be made of a requirement that both solid and liquid waste be source-sorted, stored so that no pollution occurs and transported ashore to be dealt with in accordance with rules applicable to the waste in question. ${ }^{123}$ The permit also stipulates that the applicant shall be responsible for taking restorative measures when the pipeline is taken out of service. The government is to decide to what extent the pipeline should be removed by the applicant and what restorative measures to the seabed may be required upon being informed by the applicant that the operation of the pipeline is being terminated. ${ }^{124}$

In addition to the conditions the government decision also sets out a number of 'undertakings' made by Nord Stream AG which are said to constitute an important part of the government's assessment of the application. These undertakings relate e.g. to compensation to Swedish commercial fishermen in accordance with an agreement entered into between the applicant and the Swedish Fishermen's Federation and to a commitment not to impact on locations or objects that need to be protected due to their status as part of the marine cultural heritage. ${ }^{125}$ It is not made clear why these provisions take the form of undertakings rather than formal conditions and whether that is intended to have any implications as to their binding nature or the ability to take enforcement action if needed. However, the undertakings have explicitly been taken into account by the government when concluding that the project can be carried out in a manner consistent with Sweden's obligation to protect and conserve the marine environment. ${ }^{126}$ From this it may reasonably be inferred that the undertakings are intended to be equally binding as conditions since Sweden may otherwise be unable to meet its international and EU law obligations in this regard. It must hence be assumed that the government considered these undertakings to be equally consistent with Sweden's jurisdiction under UNCLOS, Article 79, as are the conditions.

121 Request for a supplement to the application for a permit for a pipeline system under the Continental Shelf Act (1966:314) and the application for a permit to build and use a service platform under the Swedish Exclusive Economic Zone Act (1992:1140), 12 February 2008, M2007/5568/F/M.

122 Maintenance of Nord Stream Pipelines Feasible without a Service Platform, Press Release, 8 April 2008, retrieved from http://www.nord-stream.com/search/ (2013-08-23).

123 Government Decision No 15, Nov. 5, 2009, N2008/147/FIN, at 3.

124 Ibid.

125 Ibid., at 16-18.

126 Ibid., at 20 . 


\subsection{Denmark}

The Danish part of the pipeline, which passes through not only the EEZ but also Danish territorial waters, required permission from the Danish Energy Agency (DEA). The application was examined primarily in accordance with the Continental Shelf Act and the Act on State Sovereignty over Territorial Waters. ${ }^{127}$ The permit, issued in October 2009, establishes e.g. that when the pipeline is no longer in use, its decommissioning must be considered in accordance with recognized rules or international practice at the time. The applicant may in that situation be required to remove the pipeline installation. ${ }^{128}$

One condition that stands out in the Danish permit is a requirement that the applicant, i.e. Nord Stream AG, take out insurance to cover any damage caused by the activities carried out under the permit, whether or not the damage is accidental. ${ }^{129}$ A further condition focusing on chemicals holds that chemicals dangerous for the environment should in principle not be discharged into the Danish part of the Baltic Sea, but should be transported for environmental treatment on land. ${ }^{130}$

An Estonian environmental NGO appealed the permit to the Energy Board of Appeal which upheld the DEA's decision. ${ }^{131}$ The Energy Board of Appeal found, inter alia, neither evidence nor probability that the project will harm the integrity of any internationally protected areas, such as Natura 2000 sites, areas protected under the Ramsar Convention, ${ }^{132}$ or Baltic Sea Protected Areas. ${ }^{133}$

\section{$5.5 \quad$ Germany}

In the case of Germany, three different applications were required. One for obtaining a planning permission for the German territorial sea under the Energy Act, ${ }^{134}$ one for getting an approval regarding the construction works on

127 Continental Shelf Act, cf. Consolidated Act no. 1101 of 18 November 2005, as changed by Act no. 548 of 6 June 2007; Act no. 1400 of 27 December 2008 on State Sovereignty over territorial waters. Also relevant to the assessment was Executive Order no. 361 of 25 April 2006 on certain pipeline installations for transport of hydrocarbons in territorial waters and on the continental shelf.

128 Danish energy agency, Permit to Section of the Nord Stream Natural Gas Pipelines in Danish Sea Area, 27. October 2009, File no. 1110/8609-0002 (translation), at 24.

129 Ibid.

130 Ibid., at 25.

131 Decision by the Energy Board of Appeal (Energiklagenævnet), 31. maj 2010, Eksp.nr.: 49725 (translation).

132 Convention on Wetlands of International Importance Especially as Waterfowl Habitat, 2 February 1971, 996 U.N.T.S. 245 (Ramsar Convention).

133 Permit to Section of the Nord Stream Natural Gas Pipelines in Danish Sea Area, supra note 128 , at 25.

134 Energiewirtschaftsgesetz vom 7. Juli 2005 (BGBl. I S. 1970, 3621) (EnWG), Art. 43. 
the continental shelf under the Mining act, ${ }^{135}$ and a third and in this context most import one, for the assessment of impacts on the water and air above the continental shelf, also under the Mining act. ${ }^{136}$ The assessment of impacts above the shelf, including on the environment and shipping, was made by the Federal Maritime \& Hydrographic Agency (BSH) ${ }^{137}$ while the other two permits fell within the purview of the regional authority Bergamt Stralsund.

Focusing on the permit issued by BSH in late December 2009 it is pointed out in the permit that the planned pipeline will contribute to the diversification of energy transport routes, thereby making Germany and the EU less vulnerable to conflicts between gas-producing States and third States regarding transport routes and thus providing increased security. ${ }^{138}$

As to the marine environment the BSH does not expect the proposed project to entail any harm to plants or animals that could motivate a permit denial, nor marine pollution or other environmental risks as specified in the applicable legislation. ${ }^{139}$ An alternative route that would have required considerable work on the seabed within a Natura 2000 site was rejected already at the EIA stage and considerable attention is given in the permit to expected impacts on sites and species protected under the EU Habitats directive. ${ }^{140}$ Regarding the Harbour Porpoise it is noted that in addition to the habitats directive, this species also enjoys protection under both the Bonn ${ }^{141}$ and the Bern ${ }^{142}$ wildlife conventions. ${ }^{143}$

As to decommissioning of the pipeline the German authorities, like the authorities of most other States concerned, reserve the right to make the necessary arrangements for this according to the rules and international standards applicable at the time. ${ }^{144}$

135 Bundesberggesetz vom 13. August 1980 (BGBl. I S. 1310) (BBergG), dd. 13.08.1980, Art. 133, para. 1 , No. 1 ,

136 Ibid., Art. 133, para. 1, No. 2a.

137 Bundesamt für Seeschiffahrt und Hydrographie.

138 Bundesamt für Seeschiffahrt und Hydrographie, Genehmigungsbescheid, 28December 2009, at 30.

139 Ibid., at 30. See also at 75.

140 See e.g. ibid., at 63 et seq.

141 Convention on the Conservation of Migratory Species of Wild Animals, 23 June 1979, 1651 U.N.T.S. 356.

142 Convention on the Conservation of European Wildlife and Natural Habitats, 19 September 1979, E.T.S. No 104.

143 Bundesamt für Seeschiffahrt und Hydrographie, Genehmigungsbescheid, 28 December 2009, at 58-59.

144 Ibid., at 8 and 83. 


\subsection{Comparison and conclusions}

Any attempt to draw conclusions from a comparison of decisions made in different jurisdictions calls for some caution. However, a survey like the present one provides a basis for some reflections on the issues that have featured in the national permit procedures, the positions taken on these issues by the authorities concerned, and the implications thereof on the protection of the Baltic Sea environment. It may also bring some insights into the way the overlap of different spheres of law may play out in practice in a complex, transboundary energy-infrastructure project. Initially some attention is given to the general approach by national decision-makers to international and EU law, including rules on jurisdiction and on the marine environment. Thereafter some specific permit conditions are addressed.

As to the different spheres of law referred to at the outset of this contribution it is clear that the national decision-making on Nord Stream AG's applications shows, with few exceptions, considerable fidelity to international law, primarily in the form of UNCLOS. Particularly the transit States Finland and Sweden, whose basis for exercising jurisdiction in relation to the pipeline project has been the least clear among the States concerned, have both professed their intention to act within the constraints set by UNCLOS and also appear overall to have done so when assessing applications and setting out conditions. In the case of Sweden the government may have felt it particularly important to affirm its intention to act as a dispassionate interpreter of applicable law considering the strong negative opinions regarding the project aired by senior politicians. There are, however, a few points where the consistency of permit conditions with UNCLOS is not obvious. These are addressed below.

It is mostly, however, on issues of jurisdiction and the room for legitimately restricting the laying and operation of submarine pipelines that international law plays an explicit role in the permits. The general obligation incumbent upon coastal States to protect the marine environment also features in most permits. But the more detailed requirements set out in the permits are only exceptionally linked to specific provisions of international law.

Sources of international obligations other than UNCLOS, such as the Helsinki Convention and other regional agreements on environmental protection, have made few obvious marks. The obligation to apply the precautionary principle found in the Finnish permit could be seen as a reflection of the central role of precaution in the Helsinki Convention. However, Nord Stream AG is explicitly referred to as a national of Switzerland and since Switzerland is not party to the Helsinki Convention this ought rather to be seen as an assertion of the customary law nature and thus universal applicability of the principle.

Somewhat harder to square with Nord Stream AG's status as a Swiss national are the ubiquitous references to Natura 2000 and the underlying EU legislation establishing this network of protected areas in several permits. As a non-EU Member State Switzerland has not agreed to the imposition of these specific EU law provisions on its nationals. The EU Member States imposing these rules must thus consider the protective aim and the substantive measures 
of Natura 2000 to fall within the general mandate in UNCLOS to protect the marine environment. The transit States Finland and Sweden, basing their regulation of the pipeline on UNCLOS, Article 79, must even consider the Natura 2000 rules to fall within their mandate to take measures for 'the prevention, reduction and control of pollution from pipelines'. This is not, however, beyond a reasonable interpretation of UNCLOS since 'pollution of the marine environment' is given a very broad meaning in the Convention. ${ }^{145}$

As to the general relationship between domestic and international law it is also interesting to note the obligation imposed on the applicant in the Russian permit to carry out the works in compliance with the norms of international law. Although this says little about the substantive content that may be given to this obligation within the national legal system at issue, not to mention any consequences of its breach, it is at least nominally a strong affirmation of the prominence of international law in this context and as a source of immediately relevant rules for the operation in question.

All three transit States issued their decisions consenting to the project within a couple of weeks despite the initial applications being submitted at quite different points in time. This indicates a will to coordinate the procedure and, likely, facilitate the expedient commencement of the project. The fact that the project had strong political backing e.g. from Germany as well as formal endorsement by the EU through its inclusion on the European Union (EU) list of Trans-European Energy Network Guidelines (TEN-E) is unlikely not to have affected the decision making of the transit States. All permits issued by EU Member States explicitly refer to the TEN-E list.

Whether this apparent preparedness has negatively influenced the quality of the decisions in terms of environmental protection achieved is hard to ascertain. However, the Swedish request for inter alia alternative routes for the entire pipeline and a no action alternative evidences a preparedness to push for a more thorough basis for assessing the application. The initially proposed routing of the pipeline was also changed on several occasions, including during the Finnish, the Swedish and the Danish assessments, as a result of concerns raised in consultations.

Two factors in particular seem to have affected the adjustments made regarding the routing: The prevalence of dumped munitions and mines and the proximity of the planned pipeline to protected areas, notably those designated as Natura 2000. Whether the integrity of all protected areas has in fact been fully respected is not for a legal analysis to determine. It should be clear, however, that Natura 2000 and the legislation on which it is based, played a prominent role in forming the design of the project as finally implemented. The quality of the EIA and the protection of Natura 2000 sites, which are the issues most directly regulated by EU law, have also been assessed on appeal in a few

145 'Pollution of the marine environment' means the introduction by man, directly or indirectly, of substances or energy into the marine environment, including estuaries, which results or is likely to result in such deleterious effects as harm to living resources and marine life, hazards to human health, hindrance to marine activities, including fishing and other legitimate uses of the sea, impairment of quality for use of sea water and reduction of amenities UNCLOS, Art. 1 (1) (4). 
cases and found to be consistent with the requirements of EU law. Obviously, this is no guarantee for the correctness of the national assessments. National courts and tribunals are not the final interpreters of EU law requirements. However, it provides some support for the contention that the political influence to which national authorities may have been subject has not prompted them to step outside the boundaries of the law.

Partly due to Estonia's early rejection of Nord Stream AG's bid to survey the Estonian continental shelf and partly because of the applicants own decisions, the application procedures did not involve the States with the strongest political (and economic) misgivings about the pipeline, including Poland. As to the Estonian decision it did not in any apparent way constitute a transgression of coastal State obligations. Since drilling into the seabed falls within the discretion of the coastal State the rejection of seabed surveys was justified at least to the extent that the planned surveys involved such activities. $^{146}$

As noted above, some of the conditions set out in the national permits deserve specific mentioning in their own right. As to protection of the environment in general the most striking obligation imposed by any permit is probably the Finnish requirement that the project should be implemented in conformity with the precautionary principle. From the environmental point of view it may be regretted that the lack of a definition or any other specification of what this entails for the applicant may significantly undercut the practical value of this obligation. As concluded above it is, however, interesting as a statement on the general role of precaution in international law.

Although not entailing an obligation of precaution it is still noteworthy that both the Finnish and the Russian permits require the applicant to ensure minimum possible impact of the works on the marine environment in general or on its biological resources and their environment. This resonates e.g. with the obligation incumbent upon the States under UNCLOS, Articles 192 and 194 on protection of the marine environment.

A further obligation relating to the environment is the requirement stipulated in several permits to use a dynamically positioned pipe-laying vessel in the whole or in sensitive parts of the EEZ. Compared to a vessel positioned by means of anchors one that is dynamically positioned reduces the need for munitions clearance, the release of harmful substances and nutrients as well as harm to sensitive sites on the seabed.

Most permits take a similar approach to the decommissioning of the pipeline reserving the right of the competent national authorities to specify the obligations of the operator in light of the rules and principles that will apply when the pipeline is to be taken out of service. This provides for a dynamic regulatory approach enabling advances in technology and scientific understanding as well as changes of rules and standards to affect the future decisions. Apart from this, there are few signs of any intention to create an adaptive or flexible regime for regulating the pipeline over time. However, this is not too surprising considering that the brunt of the environmental impact is

146 See further Langlet, supra note 43. 
expected during the relatively short construction phase, rather than the much longer operational phase. It is striking, though, that the effect of the pipeline on the EU Member States' ability to achieve the objectives of the 2008 Marine Framework Directive is not an issue in any permit.

A requirement whose consistency with UNCLOS is not immediately apparent is the Swedish one that waste be source-sorted. It is hard to see how the way waste is treated once it is taken onshore may be subject to coastal State jurisdiction, except of course in the case that the waste is taken onshore in the State setting out the obligation. However, in that case national waste law will clearly apply since the activity then takes place on the territory of the State concerned. The Finnish requirement for recording the amount of waste and the delivery locations may be questioned along the same lines but it is easier to see how this documentation may support the objective of protecting the marine environment from harm caused by dumping or other inappropriate management of waste from the laying of the pipeline. The Danish requirement that chemicals harmful to the environment should in principle be transported for environmental treatment onshore has an even more immediate and obvious link to the protection of the marine environment.

\section{$6 \quad$ General Conclusions}

The Nord Stream pipeline project is among the largest and most controversial energy infrastructure projects in Europe. It has met with objections of different kinds. Some, including most of those having to do with environmental impacts, are linked to the specific route chosen. Others are directed more generally at the construction of a gas pipeline from Russia to Central Europe and its implications for inter alia energy security. Despite meeting with rather different reactions, both with respect to public opinion and more official statements in the transit States concerned, the formal decisions made show little obvious traces of these different sentiments. The decisions are rather characterized by a significant level of fidelity to international law. Although this does in no way contradict the fact that the decisions may have been influenced by various political considerations - particularly when decisions have been made by inherently political bodies like governments - the decision-makers seem nonetheless to have been anxious to make their decisions consistent with international law. Since all applications were granted, with the exception of the one for surveying the seabed in the Estonian EEZ - and no conditions imposed was found unacceptable by the applicant or any State concerned there has been no international legal challenge spurred by the project and only a few cases of appeal in front of domestic courts or tribunals.

Conditions imposed based on energy security considerations could have spurred conflict since they have no obvious backing in UNCLOS. However, although references are made to such considerations in some of the permits no specific conditions seem to have been based on them, thus not providing a potential bone of contention regarding the reach of coastal State jurisdiction.

The ambiguities pertaining to the exercise of jurisdiction according to UNCLOS, Article 79 does not seem to have caused any significant problems in 
this case. However, any dispute regarding the limits of coastal State jurisdiction over pipelines on the continental shelf would only have come to a head had a coastal State rejected an application or imposed conditions considered unacceptable by the applicant or an affected State. In this sense the Nord Stream project did not contribute much to elucidating the partial nebulousness of Article 79.

The environmental dimension has been significant in the national assessments and the subsequent permits. Environmental grounds have not been evidently or irresponsibly used to further policy objectives not recognized by UNCLOS. Whether the environment has received appropriate protection is hard to judge. However, the consistency of the permits with national and EU law has in some cases been confirmed on appeal. Substantive EU law has featured primarily with respect to the protection of environmentally significant areas, particularly Natura 2000 sites the presence of which have affected the routing of the pipeline to a substantial degree. The transit States concerned must have deemed the imposition of Natura 2000 requirements to fall within their mandate under UNCLOS, Article 79 (2), i.e. prevention of pollution from pipelines. Such pollution is thus seen to include disturbances caused by the laying process as well as any pollution from the pipelines as such. In view of UNCLOS' broad definition of pollution this is quite reasonable since it is, as least with gas-pipelines, the laying that poses the major threat to the marine environment. 